\title{
KEMAMPUAN PEMAHAMAN KONSEP MATEMATIKA MELALUI MODEL LEARNING CYCLE 5E BERBANTU SIMULASI DIAGRAM VENN
}

\author{
Annisa Aristia ${ }^{1}$, Andinasari ${ }^{2}$, Tika Dwi Nopriyanti ${ }^{3}$ \\ Program Studi Pendidikan Matematika Universitas PGRI Palembang ${ }^{1,2,3}$ \\ tikadwinop@gmail.com ${ }^{3}$
}

\begin{abstract}
ABSTRAK
Tujuan penelitian ini untuk mengetahui pengaruh model pembelajaran Learning Cycle berbantu simulasi diagram venn terhadap kemampuan pemahaman konsep matematika siswa. Metode penelitian ini menggunakan quasi eksperimen. Populasi dalam penelitian ini yaitu seluruh siswa kelas VII SMP Negeri 10 Palembang tahun ajaran 2018/2019. Sampel diambil dengan menggunakan teknik Simple Random Sampling, sebanyak 32 siswa kelas eksperimen dan 32 siswa kelas kontrol. Penelitian dilaksanakan di SMP Negeri 10 Palembang, yang terletak di Kecamatan Kemuning Kota Palembang Sumatera Selatan. Sedangkan waktu penelitiannya antara bulan Oktober hingga bulan November tahun 2018. Pengujian hipotesis menggunakan Uji-t Independent Sample. Penelitian membuktikan bahwa ada pengaruh positif model pembelajaran Learning Cycle berbantu simulasi diagram venn terhadap kemampuan pemahaman konsep matematika.
\end{abstract}

Kata kunci : model Learning Cycle 5E, kemampuan pemahaman konsep matematika

\begin{abstract}
The purpose of this study was to determine the effect of the Learning Cycle learning model assisted by a simulation of a venn diagram on the ability to understand students' mathematical concepts. This research method uses quasi experiment. The population in this study were all VII grade students of SMP Negeri 10 Palembang in the 2018/2019 school year. Samples were taken using Simple Random Sampling technique, as many as 32 experimental class students and 32 control class students. The study was carried out at Palembang Public Middle School 10 Palembang, which is located in Kemuning District, Palembang City, South Sumatra. While the time of his research is between October and November 2018. Hypothesis testing uses the Independent Sample t-test. Research shows that there is a positive influence on the Learning Cycle learning model assisted in the simulation of a diagram of a venn on the ability to understand mathematical concepts.
\end{abstract}

Keywords : Learning Cycle 5E model, the ability to understand mathematical concepts 


\section{PENDAHULUAN}

Dalam pembelajaran matematika, kemampuan pemahaman konsep yang baik sangat diperlukan seperti halnya sudah dijelaskan dalam Peraturan Menteri Pendidikan Nasional RI No 22 Tahun 2006 agar siswa memiliki kemampuan sebagai berikut: a) memahami, menjelaskan keterkaitan antar konsep dan mengaplikasikan konsep ke dalam algoritma pemecahan masalah secara luwes, akurat, efisien, dan tepat; b) menggunakan penalaran pada pola dan sifat, melakukan manipulasi matematika dalam membuat generalisasi, menyusun bukti, atau menjelaskan gagasan dan pernyataan matematika; c) memecahkan masalah yang meliputi kemampuan memahami masalah, merancang model matematika, menyelesaikan model dan menafsirkan solusi yang diperoleh; d) mengkomunikasikan gagasan dengan simbol, tabel, gambar, atau media lain untuk memperjelas keadaan atau masalah; e) memiliki sikap menghargai kegunaan matematika dalam kehidupan, yaitu memiliki rasa ingin tahu, perhatian, dan minat dalam mempelajari matematika, serta sikap ulet dan percaya diri dalam pemecahan masalah.

Sejalan dengan hal di atas Lerner (Ahmad, 2015) mengemukakan bahwa kurikulum bidang studi matematika hendaknya mencakup tiga elemen yaitu: 1) konsep, 2) keterampilan dan 3) pemecahan masalah. Hal ini cukup beralasan mengingat jika pemahaman konsep matematika tidak sesuai dengan yang semestinya hal ini akan berpengaruh kepada aplikasi dan pemecahan masalah matematika ataupun aplikasi dan pemecahan ilmu lainnya.

Berdasarkan tujuan pembelajaran tersebut kemampuan pemahaman konsep merupakan hal yang sangat penting dalam pembelajaran matematika dan berdasarkan hasil wawancara kepada salah satu guru mata pelajaran matematika kelas VII di SMP Negeri 10 Palembang, kurangnya pemahaman konsep matematika siswa sehingga siswa kesulitan dalam menyelesaikan soal-soal matematika, siswa cenderung hanya menghapal rumus-rumus yang ada dengan ingatan jangka pendek yang menyebabkan siswa cenderung pasif untuk mengemukakan pendapat maupun pernyataan dan pembelajaran menjadi kurang bermakna.

Di samping itu belum optimalnya penggunaan media pada pembelajaran matematika. Seperti yang diketahui, media selalu berfungsi untuk menjembatani antara masalah (objek) dan pemerhati masalah (subjek). Dengan demikian, penggunaan media dapat membantu siswa dalam mempelajari materi yang dianggap abstrak, khususnya matematika. Hanya saja bagaimana cara memanfaatkan media tersebut agar dapat mempermudah pembelajaran.

Untuk mengatasi masalah tersebut dipilih model pembelajaran Learning Cycle berbantu alat peraga. Menurut teori belajar kontruktivisme suatu prinsip yang paling penting dalam psikologi pendidikan adalah bahwa guru tidak hanya sekedar memberikan pengetahuan kepada siswa. Siswa harus membangun sendiri pengetahuan di dalam benaknya. Guru dapat memberikan kemudahan untuk proses ini, dengan memberikan kesempatan siswa untuk menemukan atau menerapkan ide- 
ide mereka sendiri, dan mengajar siswa untuk menjadi sadar dan secara sadar menggunakan strategi mereka sendiri untuk belajar (Ahmad, 2015).

Model pembelajaran Learning Cycle pertama kali diperkenalkan oleh Robert Karplus dalam Science Curriculum Improvement Study/SCIS (Trowbridge \& Bybee dalam Ngalimun, 2017). Learning Cycle patut dikedepankan, karena sesuai dengan teori belajar Piaget (Renner el at dalam Ngalimun, 2017), teori belajar yang berbasis kontruktivisme. Learning Cycle atau siklus belajar adalah suatu model pembelajaraan yang berpusat pada siswa yang merupakan rangkaian tahap-tahap kegiatan (fase) yang diorganisasi sedemikian rupa sehingga siswa dapat menguasai kompetensi-kompetensi yang harus dicapai dalam pembelajaran dengan berperan aktif. Model pembelajaran Learning Cycle memiliki 5 tahap: pembangkit minat (engagement), ekplorasi (eksploration), penjelasan (explanation), elaborasi (elaboration), dan evaluasi (evaluation) (Wena, 2014: 170). Kelima tahap model pembelajaran siklus belajar (learning cycle) ini dapat digambarkan dalam bentuk siklus seperti gambar 1 .

Daur Belajar Cycle Learning

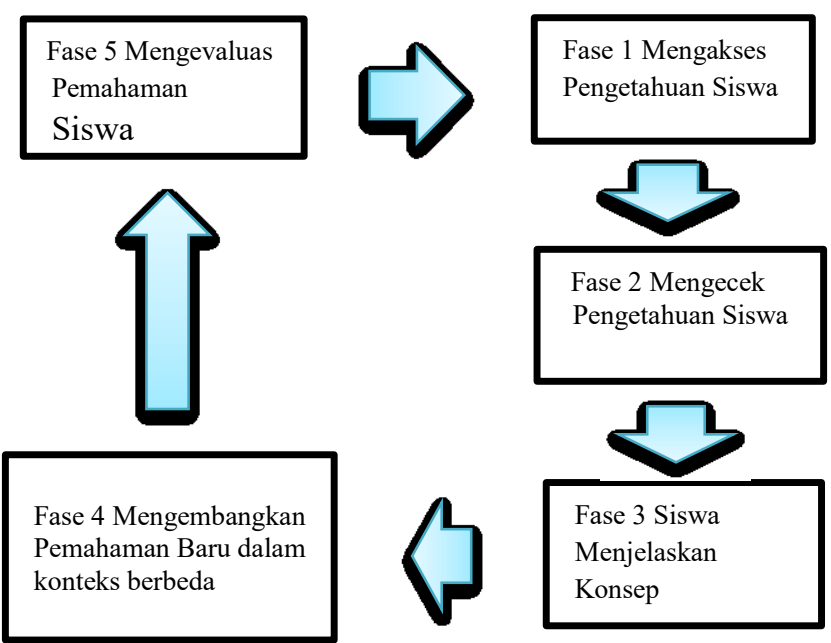

Gambar 1. Langkah-langkah daur belajar (Johnston dalam Shoimin, 2014)

Penggunaan alat peraga dalam pengajaran diutamakan untuk mempertinggi mutu belajar-mengajar. Dengan kata lain, dengan menggunakan alat peraga, hasil belajar yang dicapai akan tahan lama diingat siswa, sehingga pelajaran mempunyai nilai tinggi (Sudjana, 2014). Pada penelitian ini alat peraga himpunan yang digunakan terbuat dari styrofoam sehingga aman untuk siswa dan dibentuk seperti diagram venn, di sisi kiri terdapat contoh dan di sisi kanan terdapat soal yang berhubungan dengan himpunan.

Dengan menggunakan model pembelajaran Learning Cycle dengan berbantu simulasi diagram venn, maka siswa diharapkan dapat termotivasi dan mengembangkan konsep matematika dalam aplikasi pemecahan masalah. Melalui 5 
tahap pembelajaran pada Learning Cycle, siswa akan dapat menguasai konsep matematika yang diajarkan dengan lebih baik.

Penelitian yang relevan memuat uraian sistematis tentang hasil-hasil penelitian yang didapat oleh peneliti terdahulu dan terkait dengan penelitian yang akan dilakukan di antaranya yaitu penelitian Tampubolon (2016) tentang penerapan model Learning Cycle untuk meningkatkan kemampuan pemahaman konsep matematika siswa di SMA Negeri 1 Palembang. Hasil penelitiannya menunjukkan bahwa kemampuan pemahaman konsep siswa termasuk pada kategori tinggi.

Penelitian yang dilakukan oleh Ahmad (2015) tentang efektifitas model pembelajaran Learning Cycle $5 E$ berbantu alat peraga pada materi segitiga kelas VII terhadap kemampuan pemecahan masalah siswa. Hasil penelitiannya menunjukkan rata-rata kemampuan pemecahan masalah yang diajarkan menggunakan model Learning Cycle $5 E$ berbantu alat peraga dapat mencapai ketuntasan sebesar 76, 2419 pada batas KKM 70 (kelompok eksperimen) dengan pemanfaatan alat peraga lebih baik dari pada siswa yang diajarkan dengan konvensional (kelas kontrol) dengan rata-rata kemampuan pemecahan masalah siswa sebesar 64,1 pada materi segitiga.

Berdasarkan kondisi di atas, tujuan penelitian ini adalah untuk mengetahui pengaruh model pembelajaran Learning Cycle 5E berbantu simulasi diagram venn terhadap kemampuan pemahaman konsep matematika siswa SMP Negeri 10 Palembang pada topik himpunan.

\section{METODE}

Metode penelitian yang dilakukan dalam penelitian ini adalah metode eksperimen. Tujuan penelitian eksperimen adalah untuk melihat akibat dari suatu perlakuan. Perlakuan dalam penelitian ini diberikan pada kelas kontrol dan kelas eksperimen. Kelas ekperimen menggunakan model Learning Cycle $5 E$ berbantu simulasi diagram venn sedangkan pada kelas kontrol menggunakan pembelajaran konvensional. Perlakuan pada kelas eksperimen dan kelas kontrol bertujuan sebagai pembanding.

Tempat yang dijadikan sebagai penelitian adalah SMP Negeri 10 Palembang, yang terletak di Kecamatan Kemuning Kota Palembang Sumatera Selatan. Sedangkan waktu penelitiannya antara bulan Oktober hingga bulan November tahun 2018.

Populasi dalam penelitian ini yaitu seluruh siswa kelas VII SMP Negeri 10 Palembang tahun ajaran 2018/2019. Pada penelitian ini ada dua kelas sampel yaitu kelas VII.3 sebagai kelas eksperimen yang terdiri dari 32 siswa dan kelas VII.1 sebagai kelas kontrol yang terdiri dari 32 siswa. Pengambilan sampel dengan teknik sample random sampling yaitu dilakukan dengan cara undian.

Teknik pengumpulan data yang digunakan dalam penelitian ini adalah teknik tes. Tes diberikan sesudah pembelajaran (postes) untuk mengetahui kemampuan akhir siswa setelah diberi perlakuan. Soal tes divalidasi terlebih dahulu oleh pakar, 
lalu diujicobakan di lapangan untuk melihat kelayakannya dari segi validitas, reliabilitas, daya pembeda, dan tingkat kesukaran.

Analisis data menggunakan Independent Sample t-test untuk menguji generalisasi (signifikan) hasil penelitian berupa perbandingan keadaan variabel dari nilai rata-rata sampel dengan taraf signifikan 0,05 . Terlebih dahulu dilakukan uji prasyarat yaitu uji normalitas dan uji homogenitas untuk mengetahui apakah data yang dianalisis normal dan homogen. Semua teknik analisis data dalam penelitian ini menggunakan program SPSS 22 For Windows.

\section{HASIL DAN PEMBAHASAN}

Perhitungan data dari hasil postes menunjukkan bahwa secara deskriftif ada perbedaan kemampuan pemahaman konsep matematika kelas eksperimen yang mendapat perlakuan model pembelajaran Learning Cycle $5 E$ berbantu simulasi diagram venn dengan kelas kontrol yang menggunakan model konvensional.

Terlebih dahulu dilakukan uji prasyarat yaitu uji normalitas dan uji homogenitas untuk mengetahui apakah data yang dianalisis normal dan homogen. Hasil perhitungan uji normalitas dengan menggunakan uji Kolmogorov Smirnov Test menyatakan bahwa masing-masing kelas eksperimen dan kelas kontrol berdistribusi normal. Dari tabel 1 di bawah ini dapat dilihat bahwa untuk kedua kelas nilai Sig > 0,05, maka Ho diterima, artinya data kedua kelas berdistribusi normal.

Tabel 1. Hasil uji normalitas data

\begin{tabular}{ccccc}
\hline & \multirow{2}{*}{ Pendekatan } & \multicolumn{3}{c}{ Kolmogorov-Smirnov } \\
\cline { 3 - 5 } & Learning & Statistic & df & Sig. \\
\hline \multirow{2}{*}{$\begin{array}{c}\text { Pemahaman } \\
\text { konsep }\end{array}$} & 0,128 & 32 & 0,197 \\
& Konvensional & 0,109 & 32 & 0,200
\end{tabular}

.Hasil perhitungan uji homogenitas dengan menggunakan uji Lavene Test menyatakan bahwa varians kedua kelas homogen. Dari tabel 2 di bawah ini dapat dilihat bahwa nilai Sig $>0,05$, maka varians data dinyatakan homogen.

Tabel 2. Hasil uji homogenitas data

\begin{tabular}{ccc}
\hline $\begin{array}{c}\text { Statistik } \\
\text { Lavene }\end{array}$ & Sig. & Kesimpulan \\
\hline 2,266 & 0,137 & Homogen \\
\hline
\end{tabular}


Setelah data memenuhi syarat yaitu data berdistribusi normal dan homogen maka pengujian dapat dilanjutkan dengan perhitungan uji-t yaitu Independent Sample t-test. Hasil perhitungan dapat dilihat pada tabel 3 berikut.

Tabel 3. Hasil uji Independent Samples Test postes

\begin{tabular}{cccc}
\hline Kelas & $t$ & Sig.(2-tailed) & Ho \\
\hline $\begin{array}{c}\text { Eksperimen } \\
\text { Kontrol }\end{array}$ & 2,647 & 0,010 & Ditolak \\
\hline
\end{tabular}

Dari hasil penelitian didapatkan perbedaan pada kelas eksperimen dan kelas kontrol diperkuat dengan hasil uji-t, berdasarkan hasil perhitungan uji-t pada kelas eksperimen dan kelas kontrol diperoleh nilai Sig. (2-tailed) $=0,010$. Karena nilai signifikan lebih kecil dari 0,025 maka Ho ditolak, sehingga dapat disimpulkan bahwa ada pengaruh positif kemampuan pemahaman konsep matematika siswa dengan menggunakan model pembelajaran Learning Cycle $5 E$ berbantu simulasi diagram venn. Kemampuan pemahaman konsep siswa yang memperoleh pembelajaran Learning Cycle berbantu simulasi diagram venn lebih baik daripada siswa yang memperoleh model pembelajaran konvensional.

Tahapan tingkat pemahaman konsep siswa dalam pembelajaran matematika akan meningkat apabila seorang guru mampu menerapkan suatu model pembelajaran yang tepat, salah satunya dengan menerapkan model pembelajaran Learning Cycle. Melalui 5 tahapan kegiatan dalam model Learning Cycle, maka hasil yang diperoleh akan lebih maksimal. Pada tahap engagement, siswa dikenalkan terhadap materi yang akan dipelajari melalui cara mengaitkan masalah dengan keadaan sehari-hari, serta memotivasi siswa untuk merangsang keaktivan untuk keinginan dalam mempelajari konsep, serta memperhatikan guru. Dari tahapan inilah terlihat kemampuan awal siswa untuk menyatakan ulang sebuah konsep. Pada tahap kedua yaitu eksploration, siswa diberi kesempatan untuk bekerja sama dengan kelompokkelompok kecil, tanpa pengajaran langsung dari guru untuk menguji prediksi, melakukan, dan mencatat pengamatan serta ide-ide, melalui kegiatan-kegiatan seperti praktikum dan telaah literatur, dengan tujuan siswa dapat mengklasifikasi objekobjek menurut sifat-sifat tertentu (sesuai dengan konsepnya). Pada tahapan explanation, yaitu tahapan dimana siswa menjelaskan dan meringkas hasil yang diperoleh dan membedakan konsep yang mereka ketahui dengan hasil eksplorasi yang ditemukan. Dengan bimbingan guru siswa didorong untuk menjelaskan suatu konsep dengan kalimat atau pemikiran mereka sendiri, meminta bukti dan klasifikasi atas penjelasan siswa. Pada tahap ini siswa menemukan istilah-istilah dari konsep yang dipelajari sehingga siswa dapat memberikan contoh dan non contoh dari konsep serta menyajikan konsep dalam berbagai representasi matematis. Selanjutnya pada tahapan elaboration, siswa mengembangkan konsep dan keterampilan dalam situasi baru melalui kegiatan-kegiatan seperti praktikum lanjutan dan problem solving, pada tahapan ini siswa perlu mengembangkan syarat perlu atau syarat cukup dari suatu 
konsep dan menggunakan, memanfaatkan dan memilih prosedur atau operasi tertentu. Pada tahapan terakhir yaitu evaluation, guru menilai apakah pembelajaran sudah berlangsung baik dengan jalan memberikan tes untuk mengukur kemampuan siswa setelah menerima pelajaran, pada tahapan ini siswa diharapkan mampu mengaplikasikan konsep atau algoritma pemecahan masalah.

Hasil penelitian ini sejalan dengan hasil penelitian terdahulu yang dilakukan oleh Antika (2016) bahwa pencapaian kemampuan pemahaman konsep matematika siswa menggunakan model pembelajaran Learning Cycle $5 E$ lebih baik dari siswa yang memperoleh pembelajaran konvensional.

Pembelajaran menggunakan model Learning Cycle berbantu simulasi diagram venn dapat menjadikan siswa terlibat secara langsung dan aktif mempelajari materi secara bermakna dengan bekerja dan berpikir baik secara individu maupun kelompok. Hal ini sejalan dengan Handayani (2011) yang menyatakan siklus belajar mempunyai salah satu tujuan yang memberikan kesempatan siswa untuk mengkonstruksi pengetahuan dan pengalaman mereka sendiri dengan terlibat secara aktif mempelajari materi secara bermakna dengan bekerja dan berpikir baik secara individu maupun kelompok, sehingga siswa dapat menguasai kompetensikompetensi yang harus dicapai dalam pembelajaran.

Proses belajar model Learning Cycle berbantu simulasi diagram venn yang dilakukan di SMP Negeri 10 Palembang dengan memberikan LKS pada siswa dan membentuk 6 kelompok, kelas yang digunakan adalah kelas VII.3. Pada pertemuan pertama hampir semua kelompok masih kesulitan dalam menjawab semua pertanyaan yang ada pada LKS setiap tahapannya, karena mereka belum terbiasa dengan pembelajaran menggunakan LKS. Kemudian, pada pertemuan kedua dan ketiga mereka sudah memahami setiap tahapan pada LKS. Pembelajaran dengan sistem kelompok membuat siswa saling membantu dan mengajarkan tentang materi yang mereka pahami dan tidak menganggap adanya persaingan dengan siswa yang lain. Hal ini terbukti bahwa kelas VII.3 yang tadinya kurang aktif dalam pembelajaran menjadi lebih aktif secara keseluruhan. Berbeda dengan siswa kelas kontrol yang hanya menerima pembelajaran dari satu arah, siswa cenderung lebih pasif, dan lebih mudah bosan sehingga pembelajaran menjadi kurang bermakna dan tidak efektif. Hal ini membuat siswa menjadi sukar dalam memahami pelajaran.

Perbedaan antara siswa kelas eksperimen dan kelas kontrol disebabkan pembelajaran Learning Cycle berbantu simulasi diagram venn terhadap proses diskusi antara siswa. Diskusi dalam pembelajaran ini menuntut siswa berperan aktif dalam kelompok, sedangkan pada kelas kontrol tidak dilakukan. Dengan adanya sharing pengetahuan dalam kelompok membuat siswa yang kurang pandai menjadi lebih pandai. Hal ini dapat dilihat dari hasil tes yang dilakukan pada setiap pertemuan, kelas eksperimen memiliki nilai rata-rata yang lebih tinggi dari kelas kontrol di setiap pertemuan. Pada kelas eksperimen, pertemuan 1 mendapat nilai rata-rata sebesar 95,38, pertemuan 2 mendapat nilai rata-rata sebesar 96,25, dan pertemuan 3 mendapat nilai rata-rata 85,19. Sedangkan pada kelas kontrol, 
pertemuan 1 mendapat nilai rata-rata 70,13, pertemuan 2 mendapat nilai rata-rata sebesar 72,28, dan pada pertemuan 3 mendapat nilai 74,91.

Soal tes latihan setiap pertemuan mengacu pada indikator kemampuan pemahaman konsep. Kemampuan pemahaman konsep terdiri atas 7 indikator (Kesumawati, 2010) yaitu: (1) kemampuan menyatakan ulang sebuah konsep; (2) kemampuan mengklasifikasikan objek menurut sifat-sifat tertentu sesuai dengan konsep; (3) kemampuan memberi contoh dan bukan contoh; (4) kemampuan menyajikan konsep dalam berbagai bentuk representasi matematika; (5) kemampuan mengembangkan syarat perlu atau syarat cukup dari suatu konsep; (6) kemampuan menggunakan, memanfaatkan dan memilih prosedur tertentu; (7) kemampuan mengaplikasikan konsep/algoritma ke pemecahan matematika. Dari ketujuh indikator tersebut, indikator yang paling banyak diterapkan yaitu indikator ke-6 dan ke-7, dan indikator yang paling sedikit diterapkan yaitu indikator ke-5. Penerapan indikator tersebut sesuai dengan keperluan soal.

Berikut salah satu contoh penerapan indikatornya. Pada indikator kelima, yaitu mengembangkan syarat perlu dan syarat cukup suatu konsep yang mencapai kategori cukup dengan nilai rata-rata 63,02. Di sini terlihat siswa harus menyelesaikan soal operasi irisan yang dituangkan dalam kehidupan sehari hari. Pada soal ini siswa harus mencari berapa banyak siswa yang gemar olahraga basket dan voli terlebih dahulu sebelum siswa mendapat berapa banyak siswa yang menggemari basket saja dan voli saja. Gambar 2 berikut ini merupakan cuplikan dari jawaban siswa yang kurang tepat.

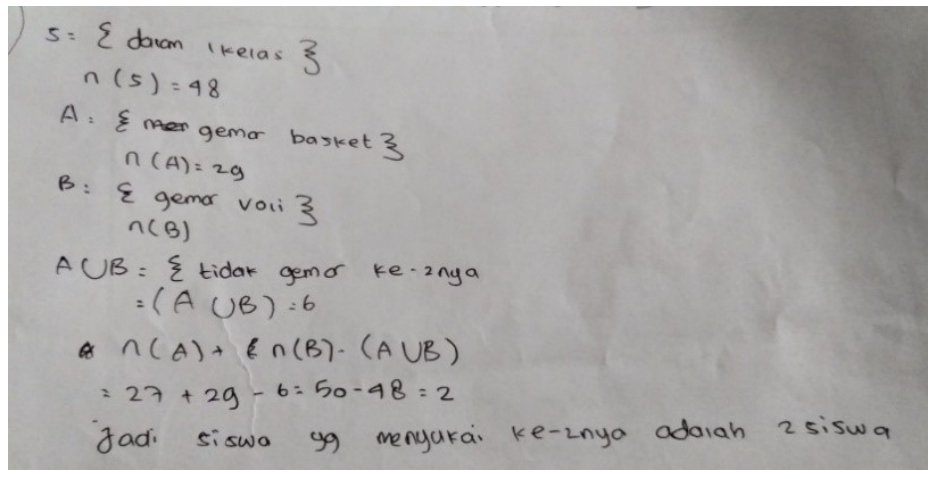

Gambar 2. Jawaban siswa yang kurang tepat dari kelas kontrol

Dari jawaban di atas terlihat bahwa siswa belum memahami cara menyelesaikan soal operasi irisan yang dituangkan dalam kehidupan sehari hari, kemungkinan hal ini disebabkan karena siswa belum memahami operasi irisan dari sebuah himpunan. Jawaban siswa yang lengkap dapat dilihat pada gambar 3 berikut ini. 


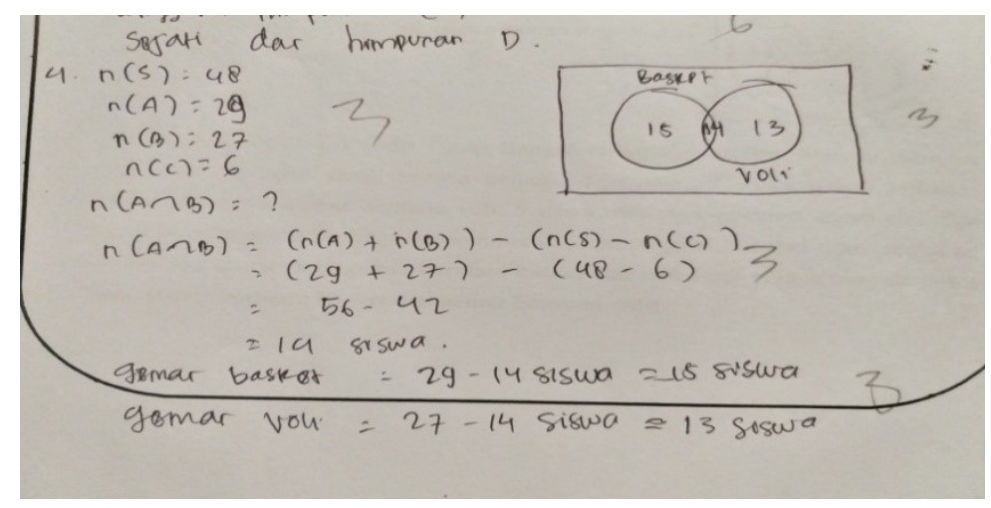

Gambar 3. Jawaban siswa yang tepat dari kelas eksperimen

Pada gambar 3, terlihat bahwa siswa sudah mampu menyelesaikan soal operasi irisan yang dituangkan dalam kehidupan sehari hari, sehingga kesimpulan akhir yang mereka berikan sudah tepat.

Hasil dari postes di akhir pembelajaran menunjukkan bahwa secara keseluruhan terdapat perbedaan hasil tes kemampuan pemahaman konsep pada kelas eksperimen dan kelas kontrol. Dimana rata-rata postes siswa kelas eksperimen sebesar 79,63 sedangkan rata-rata skor postes siswa kelas kontrol sebesar 74,31.

Secara umum siswa yang mendapatkan model pembelajaran yang tepat seperti model pembelajaran Learning Cycle berbantu simulasi diagram venn dalam proses pembelajaran akan membuat siswa menjadi lebih tertarik kepada matematika dan akan lebih bertanggung jawab dalam menyelesaikan masalah-masalah matematika. Hal ini sesuai dengan pengamatan ketika berlangsungnya proses pembelajaran dengan model pembelajaran Learning Cycle berbantu diagram venn, sebagian besar siswa terlihat memiliki inisiatif belajar, memandang kesulitan sebagai tantangan, dan terlihat antusias dalam merancang jawaban dari LKS yang diberikan walaupun ada beberapa juga yang terlihat hanya menerima saja yang dikerjakan temannya.

\section{SIMPULAN DAN SARAN}

Berdasarkan hasil analisis data dan pembahasan hasil penelitian, maka diperoleh kesimpulan ada pengaruh yang positif model Learning Cycle $5 E$ berbantu simulasi diagram venn terhadap kemampuan pemahaman konsep siswa pada topik himpunan kelas VII.3 di SMP Negeri 10 Palembang. Dengan nilai rata-rata postes siswa kelas eksperimen sebesar 79,63 yang termasuk kategori "baik".

Model Learning Cycle $5 E$ sangat baik diterapkan, karena lima tahapan yang dilakukan membantu pembelajaran lebih terarah dan terkondisi, karena itu sebaiknya model ini diterapkan dalam pembelajaran matematika. 


\section{DAFTAR PUSTAKA}

Ahmad, Shufiana. 2015. Efektivitas Model Pembelajaran Learning Cycle 5E Berbantu Alat Peraga Pada Materi Segitiga Kelas VII Terhadap Kemampuan Pemecahan Masalah Siswa. Delta, Vol. 3(1) : 63-74.

Antika, Yuli. 2016. Pengaruh Model Pembelajaran Learning Cycle Terhadap Kemampuan Pemahaman Konsep Matematika Pada Siswa SMP Negeri 44 Palembang. Skripsi tidak dipublikasikan. Palembang: Universitas PGRI Palembang.

Handayani, S. D. 2011. Pengembangan Perangkat Pembelajaran Matematika dengan Model Learning Cycle-5E Pada Pokok Bahasan Kesebangunan Kelas IX SMP Negeri Benjeng. [Online]. Tersedia: http://digilib.uinsby.ac.id/9342 [28 Februari 2018].

Kesumawati, Nila. 2010. Peningkatan Kemampuan Pemahaman Konsep, Pemecahan Masalah, dan Disposisi Matematika Siswa SMP Melalui Pendekatan Pendidikan Matematis Realistik. Disertasi tidak dipublikasikan. Bandung: Universitas Pendidikan Indonesia.

Ngalimun. 2017. Strategi dan Model Pembelajaran. Yogyakarta: Dua Satria Offet.

Peraturan Menteri Pendidikan Nasional RI No 22 Tahun 2006.

Shoimin, Aris. 2014. Model Pembelajaran Inovatif dalam Kurikulum 2013. Yogyakarta: Ar-Ruzz Media.

Sudjana, Nana. 2014. Dasar-dasar Proses Belajar-mengajar. Bandung: Sinar Baru Algensindo.

Tampubolon, Priska Damayanti. 2016. Penerapan Model Learning Cycle Untuk Meningkatkan Kemampuan Pemahaman Konsep Matematika Siswa di SMA Negeri 1 Palembang. Skripsi tidak dipublikasikan. Palembang: Universitas PGRI Palembang.

Wena, Made. 2014. Strategi Pembelajaran Inovatif Kontemporer. Jakarta: Bumi Aksara. 